\title{
Theory of Negative Political Consciousness: The Case of Reliance on the Credenda and the Medieval Justification of Political Power
}

\author{
Mehdi Shokri \\ Department of Philosophy and Humanities, Free University of Berlin, Berlin, Germany \\ Email: Shokri.phil@gmail.com
}

How to cite this paper: Shokri, M. (2017) Theory of Negative Political Consciousness: The Case of Reliance on the Credenda and the Medieval Justification of Political Power. Open Journal of Social Sciences, 5, 209-225.

https://doi.org/10.4236/jss.2017.59015

Received: July 12, 2017

Accepted: September 18, 2017

Published: September 21, 2017

Copyright $\odot 2017$ by author and Scientific Research Publishing Inc. This work is licensed under the Creative Commons Attribution-NonCommercial International License (CC BY-NC 4.0). http://creativecommons.org/licenses/by-nc/4.0/

\begin{abstract}
This paper assesses two instruments of power: the miranda and credenda of power. These instruments can be found in different power systems and regimes: in ancient Greece, Islamic medieval states or even in Modern Middle Easter states. The first approach is historical, which helps to understand the origin of the miranda and credenda of power. The second approach is theoretical, which helps to show both the miranda and credenda of power that are used to assess the claims to the justification of power. As a critique, this paper shows that semi-democracies, fascist states, theocracies, and communist regimes use these instruments excessively to justify their power. Abuse of such instrument is only possible by generating "negative political consciousness" of which aim is to make folks to become rightless and powerless. Such trend is a threat to a healthy democracy. The aim of this paper attempts to show the important role of miranda and credenda of power in justification of power.
\end{abstract}

\section{Keywords}

Negative Political Consciousness, Justification of Political Power, Politics of Miranda

\section{Conceptualization of the Politics of Miranda and Credenda in Ancient Greek and Farabi's Theory}

The most perplexing system of authoritarian/totalitarian power relies on Divine Law and Natural Law. More interestingly, in the medieval period, as well as in recent times, even common local religious leaders challenged the ongoing authority of their time in order to establish a new power structure. ${ }^{1}$ We can see that

${ }^{1}$ Due to the broad concept of this debate, I follow the transition of thought from ancient Greek to Farabi, the most prominent political theorist of medieval Islamic period. 
the result of most revolutions in the religious societies-especially in the Middle East-was different forms of theocracies. At least, this was the first step to establish authoritarian/totalitarian power structures. One argument in the favor of such transitions is Aristotle's theory of mixed government or semi-democracy, in which authoritarian/totalitarian power structures are considered to depend on a limited number of virtuous men (Barker, 1959: p. 112 [1]). Aristotle to some extent tried to argue for the right to participate in power. He argued not only in the case of Plato's philosopher-king, but also for some free men who were admired for their arbitrary virtues. Such a change between the thoughts of Plato and Aristotle in terms of the distribution of power demonstrated some form of rational-normative politicization which helped to move from an absolute authoritarian/totalitarian regime toward a hybrid one (Aristotle, Pol. III [2]; Svolik, $2012[3])$.

Admittedly, sometimes the study of the history of each state, its region and its prevailing tradition and political discourses can explain its criterion or concept of excellence more than looking at the process of rational patterns of politicization. For example, the communist takeover of 1949 in China or Islamist takeover after the so called "Arab Spring" in the Middle East are not the revolution caused by-our theory of-the political consciousness but some form of movement which heavily affected by a continuation of the imperial or religious autocratic traditions (see Fu, 1993 [4]).

Researchers involved in forming collective opinions, judgments, and political decisions (Ariely, 2008 [5]; Kuklinski \& Quirk, 2000 [6]) have asserted that decisions made by human beings, especially authorities, in the process of politicization are heavily based on heuristics and are susceptible to memory biases that limit the amount of information and experience that they are able to use (Schacter \& Addis, 2007: pp. 773-786 [7]). Hence, after the governance of an absolute authoritarian/totalitarian regime, a healthy democracy is less likely than other forms of oligarchic and theocratic regimes, since the biases such as the use of ideology for political control, concentration of power in the hands of a few, states power over all aspects of life, religion and law as the tools wielded by the rule, and the subjection of the individual to the state still exist in the political tradition of the region (Foucault, 1998: p. 92 [8]). Yet, we ask how we can find a politically understandable pattern of power transition?

The process of transition to other power structures is slow and fragile, but revolutions and regime changes may be quick. We must differentiate between these two in order to understand that those people who come from the lower classes, often discriminated against, use different opportunity, whether in economic or political crisis, to claim power against the highest class. When the process of transition to other power is not compatible with the process of politicization, the result will be the political disaster.

${ }^{2}$ The revolutionary wave of demonstrations and protests occurring in the Middle East and in North Africa since 2010. The economic crisis led the population of several countries to defy their authoritarian governments. 
The justification of these claims to power can be based either on traditional power relations, virtuous elements, religion or belief (Taylor, 1994: p. 54 [9]; Taylor, 1985: 183-229 [10]), rational merits, or even on all of these sources (Hayek, 1944: p. 135 [11]). The miranda is the traditional way of justification of power. An authority based on the miranda of power claims to power based on different forms of admiration. Different form of gods, in the beginning, and the patriarchal regime, later, are examples of power structures in which miranda of power has been exercised for centuries.

In the beginning of history of states, powers were gods and the sons of the gods. A primitive process of politicization changed power of gods and the sons of gods from an unknown and metaphysical authority to a perceptible worldly concept of authority. This was a turning point from an insecurity to a respect to the concept of creation and protection. Power emanated in the face of fathers (Filmer, 1980: ch. 1:8 [12]; Filmer, 1980: ch. 1:1 [12]), mothers and uncles. Patriarchal and matriarchal positions were the source of justification of power in different personalities and offices (Filmer, 1980: ch. 1:1 [12]). Traditionally, the most common reason for obedience to such powers was no reason at all (Merriam, 1934, p. 120, [13]). Powerful were grumpy, but not brutal or terrifying. Jove associates love and power (Godwin, 1806: p. 197 [14]; Merriam, 1934: p. 109 [13]), exemplified by rulers adorned with garlands, smiles and jovialness. No other power relation has developed such moving imaginary for the human race as the one in which people enamored the patriarchal and matriarchal positions as god-like authorities. The main achievement of the ancient authority was to convey people of their power of creation.

However, the miranda of power is one of the main instruments not only for authorities but also for those who make a claim to power by which the vicious nature of a leader's character and the rise of an authoritarian/totalitarian regime move in parallel. Abu Bakr in Saudi Arabia, Yogi Adityanath in India, Talat Pashas in Turkey, Hassan Nasrallah in Lebanon, Mao Zedong in China, and Adolf Hitler in Germany are among the leaders who used the opportunity of the claims of the lower classes for their own transition to power. They aimed to build an authoritarian/totalitarian power by using the prevailing autocratic tradition beneath the political discourses of their time. Thus, it can be argued that what seems to be the worst product of the authoritarian/totalitarian regimes is also the "accidental" byproduct, supported by the leaders (Hayek, 1944: p. 135 [11]). Authoritarian/totalitarianism regimes can thrive on this phenomenon.

Lacking in resources is, in fact, unquestionably relying on either force or on the miranda of power, and consequently, makes the claim to power autocratic. However, autocratic form of power mostly is unaccountable and dangerous for the immunity of regime. The solution to this problem was to change the traditional concept of miranda of power and to move it one step further-authorities mixed the beauty of miranda of power-admiration-with the force of religion - belief-in non-rational divine law. This partially compensated for what Plato's 
political thoughts suffered from, the concept of belief in divinity of power.

Plato discussed the justification of divine law and the authority of philosopher-kings, through a guise of rational principles. However, a direct connection between the concepts of divine law and political power were mainly found in the medieval era. In this period, a systematic form of justification, based on the concept of "belief" began to cause serious theo-political questions on power. Inquiry started into the concepts of the household and the state, in which claims for adoration, obedience, and worship of divinity had once been the famous approaches for their numinous justification (Sternberger, 1986, p. 23, [15]). In Farabi's theory of the state, the theo-political problem centered on the idea that, the traditional concept of admiration of power lost its position due to the prevailing concept of religious power. Thus, the traditional concept of admiration of power changed to the concept of belief-in divinity of power. In this sense, the miranda of power has remained excessively dependent on folks' belief in the "divine law", which is assumingly sent down by the God. Consequently, they also believed in the "divine power" that can only be exercised by religious men, "who [are] not subject to any higher person" (Fakhry, 2002: p. 103 [16]; Mahdi, 2001: p. 17 [17]). The concept of the miranda of power, which was one of the important and traditional instruments used for the justification of authority for Plato's philosopher-kings and Aristotle's virtuous men, almost lost its role through the emergence of religion. The role of religion helps power to justifies themselves. Consequently, the credenda of power became a better alternative for power holder.

Having a historical look, we can find the emergence of political religion-the emergence of credenda of power-in the medieval age. Farabi, as a political theorist, was challenged by the emergence of political Islam (Shokri, 2013: p. 37 [18]). The new concept of belief-as a prevailing concept of political Islam- had changed the political discourse of his time. Farabi found that the credenda of power, the concept of religious belief, was one of the main instruments of an authority. He understood that since the emergence of political religions, the credenda of power had been the instrument used exclusively by the Prophet-lawgiver, religious man (Mahdi, 2001: p. 19 [17]). These authorities were represented themselves as divine and privilege by God, despite the fact that they were always members of the general public.

What has always been ignored by regimes, e.g. theocracies, that have relentlessly relied on the credenda of power as their only and most important instrument, is not only the historical process of interaction between folks and power, but also the fact that the pragmatic and primary transformation of the miranda of power into the credenda power was shaped by the hands of worldly leaders whose only concern was authority (Simmons, 2001: p. 27 [19]; Merriam, 1934: p. 31 [13]; Fu, 1993 [4]). Whether power was bestowed by God or the creation of their own imagination, at the end of the day, they were rulers and the rest were ruled by them. The only important thing for an authority that merely relies on 
the credenda of power is not whether God gave this power to them, but how they can maintain the status quo and control over folks. Even in today's religiously anointed regimes, folks could be asked to obey those in authority and may warned to not ask them of anything.

However, the credenda of power, as an instrument of power does not only belong to the politics of medieval Islam-though Islam is hard to be separated from political Islam-but also to other civilizations in both the East and the West, from the Japanese to the Roman Empire (Simmons, 2001: p. 27 [19]; Barnard, 2001 [20]; Arendt, 1986 [21]; Nye, 2004 [22]).

In Sociological and Legal Concept of State, Hans Kelsen, a renowned German political and legal philosopher argues the emergence of the miranda and credenda of power was in different regimes and in the hand of a long list of various personalities. He elaborated that

the need for adoration, the need to subject oneself to a higher, a holy one, to sacrifice oneself, in short all of those human instincts toward self-diminution, abnegation and even self-destruction, find their satisfaction in any deification of the state, in any fetishism of the state that is pushed beyond rationality, and whose consequences we can state from close experience. On the other hand, there is the will to power of one person who does not content himself with a struggle with the victory of a special god on the path to the identification of a single individual with his God. For he is content only with the victory of his own personality and so, in view of the waning of the idea of God, seeks his mask in the state alone (Kelsen, 1928: pp. 249-250 [23]).

Seeing this in a specific historical context, there is a brief span between utilization of religion in the Christian politics and in Islamic politics. Such utilization introduced the credenda of power. Evidence of the use of the credenda of power for justification of power in Christian politics may go back to Charles the Great (died in $814 \mathrm{AD}$ ), a medieval Christian king. In the history of Christian politics, the credenda of power in the hands of popes-the heard of medieval catholic church-positioned the state as a fortress of religion, and used religion for mass control and to justify its own political authority (Lynch and Adamo, 2014 [24]). Similarly, in the history of Islamic politics, the credenda of power in the hands of Caliphs and other religious men positioned their offices as a fortress of religion for mass control and to justify its own political authority.

The credenda of power plays a strong role in the justification of power based on the effectiveness of a religious belief on the people, as the miranda of power is based on non-belief form of admiration (Sternberger, 1986: pp. 23-24 [15]). Thus, it can be seen that either the miranda or the credenda of power is the instrument of power from time to time and from place to place that helps power to thrive.

In the era of medieval Islam, the concept of patriarchy within the concept of 
political power, i.e. the miranda of power, lost its strength and was manipulated by new innovative forms of justification based on the belief of folks (Lynch and Adamo, 2014: pp. 65-80 [24]). The waves of politicization and the emergence of political religion helped religious men to rise out of traditional hierarchical power structures. However, the claim of religious leaders to power was not equivalent to the claim of Plato's philosopher-kings, who had the time and luxury for engaging in philosophical debates, nor was it based on the Aristotle's argument on the rational virtues of rulers' wisdom (Plato, 508-509 [25]). Thus, how could both groups, the religious leaders and the philosophers, claim power?

Farabi interpreted the ancient Greek concept of wisdom, which can be attained through philosophy, as similar to the concept of imitation that can be attained through religion (Fakhry, 2002: p. 106 [16], Mahdi, 2001:p. 17 [17]; Shokri, 2013: p. 39 [18]). The claim of religious men to power relied on divine law and "dignity" (Sternberger, 1986: p. 24 [15]) of which law was introduced in religion and followed by the virtues of imitation. Thus, the theocracies and other forms of regimes which excessively rely on the credenda of power set forth the frameworks in a shell of a legal order. In Islamic terminology it is called Sharia Law (Shokri, 2016 [26]) for people by which they should imitate Caliphsor pops. Following, if a Caliph claimed the support of such laws, then the Caliph politically supported their justification with the credenda of power. He used the religiously anointed laws and orders as an instrument- the credenda of power- to shape and to preserve the belief of the folks in a political regime through their religion. So far, it is perplexing that Farabi stressed that "religion is an imitation of philosophy" (Farabi, p. 44 [27]). This could be a starting point for other research to explore the relationship between the esoteric and exoteric teachings of Farabi. In this work, however, we maintain our concern on power and its characteristics.

Transitions between authoritarian powers were only possible through a political invention which is introduced in the medieval era. The invention was the credenda of power. It is an instrument for controlling folks and thereby justifying power (Merriam, 1934: ch.4 [13]). In this sense, we can see that a backward transition in argument of time over the power origin in philosophy to power origin in religion (Farabi, 1985 [28]; Nasr and Leaman, 1996: p. 190 [29]). We can see that Farabi's virtuous state is based on the assumption that philosophers, prophet-lawgivers or virtuous-religious men are the same and wise, yet aim to imitate the ideal, while they assume that the rest of people possess only unexamined, common opinions (Farabi, 2010 [27]). Based on this idea, the credenda of power was used when the political thinkers tried to justify the connection between an absolute authority and religiously anointed virtue.

In all modern theocratic regimes, symbolism in politics is seen as identical and important as imitation in religion, and both are critical instruments for creating and maintaining unity in a community and controlling folks. This can also be seen in a close examination of the second part of Farabi's The Political Regimes 
as well as The Perfect State. Symbolism and imitation go hand in hand and are among a long list of different elements of the credenda of power. Symbolism and imitation, in the religious sense, are vital for producing an image that is similar to the concept of knowledge in political philosophy (Farabi, 1985: p. 279 [28]).

Having said this, symbolism and imitation create a communitarian ideology in which "brothers" are made out of folks. In this sense, folks are not just considered members of a state, but as a result of the instruments of power, they are presented as a big family. The concepts of the miranda and credenda of power thus produce the concept of nationalism or even the concept of "Bruderschaft" (Campagna, 2010: p. 154 [30]), by which the level of their intensity depend on the formers. This is how the historical-political process of a society shapes the instruments of power. In the case of the credenda of power, which was firstly introduced in the medieval politics and, based on the concept of belief in power, compensated the weakness that may be found in the miranda of power.

Farabi understood the problem of power in his time. He merged the power of philosophers and religious men, as if they are the same. They were not the same in existence, but from a pragmatic point of view, both used similar instruments of political power. So far, it is still unclear if he did this in favor of Plato's philosopher-king or in favor of religious Imam. Regardless, the attempt to change philosophy to religion and to justify a religious hierarchical state (ReligiöseHerrschaft), may not have been among Farabi's main political goals, but it could not be escaped as a consequence of his ideas. The hierarchical virtuous state, which he called as "the perfect state", was instead a deceptive and authoritarian religious state, in which the miranda of power of the philosopher-king transformed to a credenda of power of a prophet-lawgiver or Imam. Yet, Farabi intended to argue for the same nature of power as Plato defended.

Farabi relentlessly relied on Plato's idea of the state in Republic by theorizing one very similar (Farabi, p. 35 [27]; Campagna, 2010: p. 152 [30]; Hammond, 1947: p. 52 [31]). Nevertheless, he was certainly aware of the differences between his system of thought and that of Plato and Aristotle. At least Farabi's ideas of divine law and position of high intellect were shaped by the social context of medieval Islam, and were explicitly influenced by the idea of God's rule and Islamic theocracy. It is also true that the exact Plato's ideas of divine law and "the ideal state" cannot be found in Farabi's ideal state. The genius move for Farabi was altering the concept of the authoritarian virtuous regime to the authoritarian/totalitarian and theocratic one.

Here, we must ask why Farabi insisted that "the idea of Philosopher, Supreme ruler, Prince, Legislature, and Imam is but a single idea"? (Farabi, p. 47, [27]; Nasr and Leaman, 1996: p. 190 [29]) Maybe the answer is simple, and easier to find that expected: the form of power structure and power relationship that both philosopher-king and Imam (religious man or Prophet-lawgiver) require are, in fact, alike. All the same, they require different conceptualizations in different states. At least, it is clear that there was no fundamental difference in the practice of power in various forms of authoritarian regimes, whether they used divine or 
traditional law for justification, they excessively relied on either miranda of power or credenda of power. Similarly, the most common, and at the same time uncommon point, is the link and the difference between miranda in the ancient Greek concept of power, and the credenda of power in the medieval and modern concept of power. As for Plato and Farabi, this authoritarian hierarchical power structure was perfect and natural (Farabi, 1985: p. 235 [28]), and the miranda and credenda of power were also deceptively assumed to be natural.

\section{The Justification of Farabi's Prophet-Lawgiver: The Excessive Reliance on the Credenda of Power}

It has been a long time in the world of politics that religion assesses the justification of power. As the result of such interaction, credenda of power became one of the main instruments of authorities.

Farabi stands in the tradition of such transaction between power and religion. The Prophet-lawgiver of his time recruits his followers from the mass. They require no particular hereditary, class, or economic background, but only the religious knowledge and ability to interpret divine law. As their masculine authority relies on the religious law and their interpretation of it, they present a credenda of power in which questioning it is regarded as the most serious crime (Plato, [32]). The claims to the power of prophet-lawgivers, are not debated, as they are already sanctioned by a direct and unimpeachable scale of divinity. Their claim to power, which Farabi identified as merely relying on the credenda of power, requires there "remains no room for intellect, consideration, deliberation, or reflection with respect to what he says" (Farabi, p. 82 [33]). Farabi saw how ancient Greek divine law hid behind the guise of religion, but the hierarchical power structure remained the same. Such law has overrun Middle Eastern and African countries ever since. Through a close examination, it can be seen that in most parts of the Middle Eastern and African states, authorities are not only monopolized by the religious men, but also that the act of questioning their principles will be punished by the death penalty. Perhaps, the only way that decadent Kingdoms can be replaced as the center of Middle Eastern state authorities is either by punishments of death and through revolution. Although the price paid, and that is still being paid, for their achievement must still be considered.

In The Attainment of Happiness, following Plato, Farabi argued that "the prince occupies his place by nature" and by his virtues (Fakhry, 2002: pp. 103-104 [16]), and that this occupation, in fact, surrounded a natural order (Farabi, p. 34 [27]. Farabi and Plato proposed twin political structures and power relations; one lived in ancient Greece and the other in the Islamic Persian kingdom.

Moreover, Farabi, just like Aristotle, used the theory of naturalness and the comparison of the "head of a household" and the "head of a state" in order to bestow the idea of fatherhood onto the authority of his prophet-lawgiver and to secure its high place in the hierarchical power structure (Farabi, p. 31 [27]; 
Steinschneider, 1966: p. 66 [34]). In this way, he tried to bridge the gap between the miranda and the credenda of power. Here, the authority of religious men and the authority of his lawgiver were the same through the combination of the miranda and the credenda of power so that folks, which he described as "vulgar" and "multitude" (Farabi, p. 42 [27]), admired the splendid authority of his prophet-lawgiver, or Imam, and that they continuously believed in the naturalness and rightfulness of him. In this way, the prophet-lawgiver easily became the head of the state with the privilege of controlling individuals. The justification of the authority of the Imam is the ability to employ "whoever and whatever" (Farabi, p. 37 [27] he wants to reach the ultimate end of the state (Farabi, p. 32 [27]). Farabi explicitly put the rights of prophet-lawgivers and his privilege above the rest, as argued that he is the one "who does not need to be ruled by a human in anything at all" (Farabi, pp. 78-79 [35]). The traditional admiration of folks for authority then turned to be the belief thereof, which was controlled by the unquestionable force of divine law. Such an approach to the divine authority of a ruler goes beyond written manuscripts and law (Mahdi, 2001: p. 17 [17]).

Farabi's approach to the credenda of power of prophet-lawgiver implies the same principle of leader with the arbitrary characters found in ancient Greek thoughts, who is entitled to control folks, based on his naturally divine superiority (Spearman, 1934: p. 158 [36]). He is not selected by the fact of heredity, or because he is Aristotle's virtuous man, i.e. the rich and white Greek upper class. For Farabi's prophet-lawgiver, neither the indication of capability for high political office of state, nor the proof of traditional or biological descent is the decisive criterion for the justification of his claim. Farabi's prophet-lawgiver is eligible to claim power and to deny the rights of others based on the arbitrary character of his divinity and his art of kingship. Yet, this acts as a privilege for controlling the rest is assumed to be "equipped for them by nature: that is in those who possess superior natures with very great potentialities" (Farabi, p. 34 [27]). The justification is not limited to the legality of a system or the rationalization of norms and values. The credenda of power works all the way to justify the power of the prophet-lawgiver. Even so, it makes the prophet-lawgiver an eligible competitor in the on-going miranda of power. This is seen in history through how the credenda of power of Prophet-lawgivers make their way to the high office of a political structure, despite the high cost for folks and the community. This emergence of authority, which merely relies on the credenda of power, is not based on the rational-normative principles of folks, or deliberative participation, as Aristotle partially implies, but merely on the concept of belief-the belief of folks in the infallible power of their rulers.

Though The right divine of kings to govern wrong [1y] (Hone, 1821 [37]) is an unusual statement today, at least its sophisticated and aristocratic defenders do not deny that kings, philosopher-kings, and virtuous men could govern wrongly. This appears more in Aristotle's Politics - that such fault is the sin and immorality of a man. However, some medieval and modern deifiers of the state practice a 
doctrine of Divine Right far more uncritically than Filmer and Hone. The character of credenda of power requires that the divine or religious law be infallible; their rulers, , e.g. Caliph or any other kind of ruler, dedicated People, cannot do wrong, morally or intellectually (Jouvenel, 1948: p. xvii [38]).

Farabi's prophet-lawgiver, also take a point from the authoritarian/totalitarian role of the philosopher-king and Aristotle's mixed government, in the potential of mastering the people, who laid down his theory behind the lightning picture of divinity. Farabi's ruler avoids the implication of rational dicta, while simultaneously and discreetly avoids rationalizing his credenda of power. Therefore, the firm and rationalized authoritarian/totalitarian structure of power are similar as in Farabi's political thoughts, in which the prophet-lawgiver occupies the highest office of the state (Farabi, 1985: p. 277 [28]; Farabi, 1961: pp. 37-38 [39]); and individual rights are denied not by the hands of prophet-lawgiver, but by the command of the infallible divine law ("<Faith> schütz unfehlbar gegen Schnupfen.” Weber and Winckelmann, 1969: p. 299 [40]). The credenda of power sells a brand of morality where the moral norms are the first victims of ignorance of political consciousness. The closest example of such an idea is authoritarian/totalitarian Islamic Caliphates in both the Medieval and modern periods and under the various form of regimes (Shokri, 2016 [26]).

However, the same historic experience raises further critiques of the validity or the credentials of prophet-lawgivers. Among these critiques are: How can one practice critique on a true prophet-lawgiver and distinguish them from those who are fraudulent? (Nasr and Leaman, 1996, p. 190, [29]) How can we detect the negative political consciousness and apocryphal character of religious personalities that shape beliefs of people? (Weber, 1969, [40]).

Here, we discuss the penetralia of power, in which no one has mapped and few have ever attempted to explore. It is neither attempt of this work to present a critique of religious laws. The aim is to assess the concepts of the miranda and credenda of power in relation to authority and political rights. In this sense, to get back to the original arguments on these instruments of power, we see how Farabi's proposal for the ideal power structure and his concept of the prophet-lawgiver share similarities with the authoritarian/totalitarian power structures of Plato and Aristotle (Mayer, 1950: p. 392 [41]). We look at how these two views attempt to justify power by using the miranda and credenda of power, and why, in practice, many have failed to justify it through an argument based on political conscious theory.

Among Farabi's various pieces of political writing, he focused on the Attainment of Happiness and On The Perfect State (Rislahfi Ara' ahl al-Madnah al-Fadila or Mabādì Arä Ahl al-Madina al-fäżela), and discussed ideas of justification of (or criteria for) power, and the justification of hierarchical virtuous state. However, a slightly different idea from Farabi is his work called The Aphorisms of the Statesman (Farabi, 1961: pp. 37-38 [39]).

Indeed, it may be assumed that the different approach of Farabi to the same 
matter is because that he was a political philosopher who stood between two worlds. Though the connection that Farabi felt, and the influence he gained, from the ancient Greek philosophers, one cannot ignore the historical and regional differences from which these men came from. To this extent, another study would be required to examine whether Farabi esoterically tried to increase the qualitative criteria on which a religious ruler should rely for the sake of his ideal philosopher-king, or in order to secure the place of religious rulers in the Islamic power structures. This is, unfortunately, not the main purpose of this small work. Whatever the answer to this question, it does not affect our assessment of the power structure that Farabi praised. Whether or not he succumbed to the influence of his time and to the regime he served, any argument about power structures in which the rulers and their authority are justified by divine or religious law leaves no question that these regimes rely heavily on the credenda of power (Farabi, 2011 [42]).

In summary, analysis of both medieval and modern hierarchical power relations must attentively consider the credenda of power. The power of those who try to justify themselves as authoritarian/totalitarian prophet-lawgivers, merely hinges on the concept of the credenda.

For Farabi, the theo-political problem begins when the credenda of power, as one of the instruments of power utilized by the religious rulers comes to light. Farabi knew that the erosion of the credenda of power is inevitable due to the "translation movement" and the increasing influence of Greek political works in the medieval Islamic world.

In On Political Government and Aphorisms of the Statesman Farabi tried to address this theo-political problem. In his attempt to escape from the theo-political problem of his time and the erosion of the credenda of power, Farabi distanced his prophet-lawgiver, from a purely religious picture. Instead he was described as using certain personal categories. In part 29 of the Aphorisms of the Statesman, the manifestation of virtuous men is clear in which Farabi's ruler (in line with Aristotle) was adorned with virtues (Desmond, 2011: p. 158 [43]) and art Farabi, 1961: p. 106 [39]). In fact, Farabi used the Platonic political structure of the ideal state and the logic of Aristotle's virtues politics, and argued that the science of religious law and theology (figh) are ancillary to the science of politics in order to make a strong credenda for authority, and religious men may be virtuous men, at the same time as lawmakers and kings.

Though the characters and elements of power may differ when we compare the matter of justification in Farabi's political theory, it is more important to look at the power relationships and the power structure. Looking at a bigger picture, we realize that not only the nature of power but the way power practices authority remains the same in both ancient Greek political theory and in that of Farabi. Philosopher-kings, virtuous men, and Imam are regarded as the head of the state. The nature of their power and the political offices that they hold are more similar than the personality of rulers and their methods of claiming power 
(Desmond, 2011: p. 158 [43]). Both Plato's philosopher-king and Farabi's Imam based their claims to power on the "naturalness" theory of state, and consequently, their natural privilege in the power structure.

The common point between Plato, Aristotle, and Farabi is the core essence of their arguments. Their arguments centered on what a state requires as a natural hierarchical power structure. What changed in medieval political theories from those in ancient Greece was the transformation of the miranda of power to the credenda of power. The excessive use of the instruments of power in Farabi's model of the state is as same as the ancient Greek model of hierarchical authoritarian/totalitarian state. However, the admiration of power changed into an excessive belief in political theology, revelation, faith, or all together: the credenda of power (Farabi, 1985: p. 279 [28]).

Nonetheless, after the establishment of an authoritarian/totalitarian regime that merely relies on the credenda of power, the system begins to introduce new virtues. Since most of the time the credenda of power manifested in the figures and personalities, the level of acceptance of virtues promoted by the credenda of power merely depends on the level of the manipulation of the rulers and the personalities based on the assumed virtues-al-madina al-fadila and tehsil al-sa'ada. This is why personality cults are the hallmark-and primarily a consequence rather than the cause-of established autocracy.

In this sense, we can argue that the manipulation of the rulers whose rely on the credenda is the same characteristic which Farabi argued for. He named two admirable traits for wielding such power: persuasion and compulsion (Farabi, p. 36 [27]). Thus, where the divinity of divine law supports persuasion, the justified authority supports compulsion. Moreover, there was the assumption that the responsibility of the prophet-lawgivers, is secured through the presumed connection to God (Desmond, 2011: p. 158 [43]). Folks felt a divine responsibility, which reached its maximum at this time when religious rulers decisively represented the almighty. The traditional inner and external compositions of beauty and force added up to belief to form the credenda of power. Though this instrument of power helps its justification, an excessive reliance on it prevented a community from moving further toward critical thinking. Hitherto, Farabi's method of justifying the power of Imam, which is maintained in today's modern theocracies, stuck strongly to the credenda of power. The mere reliance on the credenda of power by the rulers of Farabi's virtuous state or any authoritarian/totalitarian power is evidence that they do not appreciate any concept of political consciousness.

In sum, in Farabi's works, the doctrine of the virtuous state is placed at least one level below the theory of the authority of the prophet-lawgiver, Imam, or king, whose power is religious and fraternal. It may be assumed that the religious leader, who appears in the figure of the prophet-lawgiver or Imam, is in a sense more virtuous than those justified to be in power by the ancient Greeks. This may be because this form of authority not only places his emphasis on religious 
rules, but also on the normative extension of the religious rules. However, even if such assertion is a considerable one, it leaves us to wonder whether this divine criterion also forces the authority to act in the same line of moral principles. Second, we can see that this special form of the hierarchical structures has always used the virtues and massive propaganda to build a trench against repudiations and critiques. Islamic regimes, even in Farabi's age, tried hard to change the literature, culture, symbols, and history that were used in previous or co-existing political systems; different laws, historical approaches, stories, textbooks, propaganda were used in the same manner. Therefore, the nature of different religious regimes means that each has opposite principles, of which they see their own as virtuous and the others as vice.

Let us look at the bigger picture. In French Revolution, there was a determined effort to change the French dialect, which was established by former, ancient regimes (Gentile, 2006: p. 9 [44]). After the Turkish War of Independence in 1923, there were successful reforms in every aspect of social affairs (Saikal and Schnabel, 2003 [45]; Lewis, 1999: p. 66 [46]). What we learn from these examples is one simple but vital principle: there is a nuanced difference between the justifiable claim to power and unjustifiable claim. Justifiable claims may be based on the credenda of power, such as in Turkey's experience of modernization, but unjustifiable claims mostly and excessively relied on the credenda of power.

Thus, when the power of a regime is analyzed, one element to be considered is to what extent it relies on the credenda of power. There are many historical examples of transitions to different political power structures, whether in Farabi's age, in which states shifted into Islamic form of power, or in contemporary times, when China and Russia became capitalist economy yet are quasi communist regimes (Harper, 1929: pp. 956-971 [47], and recently, in the Middle Eastern countries, which are transforming into different forms of autocracies. However, one common point between all of these regimes is their excessive reliance on their miranda and the credenda of power.

\section{The Justifiable and Unjustifiable Credenda of Power}

Although the credenda of power and charismatic leaders are effective tools for creating and maintaining a harmonized state, they can also be used for justifying authority and thus increasing power. This list of leaders is by no means limited to the old or new aristocracies and theocracies; democratic power structures and Solomon-like institutions also come to force and add to the meaning of governmental miranda and credenda. The Lincolns, Churchills, Mazzinis, Anthonys, Gandhis, Roosevelts, and a long list of others, have enhanced the prestige of power (Merriam, 1934: p. 111 [13]). This is important, as the pure credenda of power on its own is not democratically praiseworthy because it produces negative political consciousness (Merriam, 1934: ch.4 [13]; Arendt, 1948 [48]).

Hitherto, the justification of credenda of power was directly related to the justification of the authority that it exercises. However, like authority, the credenda 
of power per se can also be assessed theologically. One important determining factor of whether the development of the credenda of power is justifiable or not, is that it is possible to distinguish the purpose for which means are employed. The second determining point is whether the credenda of power can be assessed with rational normative principles. An unjustified credenda of power is produced and defended merely by itself. These two important points are seen in various forms and under the different circumstances in the hierarchical authoritarian/totalitarian power structures of autocracies, theocracies and communists regimes. From time to time, autocrats, theocrats, and communists have proposed not only to destroy previous credenda of power structures, but also to destroy the identity of individuals or personalities who helped shape the previous credenda of power or those personalities who oppose the new one. Moreover, autocrats, theocrats and communists, in one way or another, do not tolerate freedom of speech, individualistic religion, private property and capitalism, as they must repress these concepts in order to build their own (unjustified) credenda of power, as their only instrument of authority (Sternberger, 1986 [15]).

\section{Conclusions}

This paper assessed two polygons of power or two instruments of power, as they originated and were practiced in different regimes, in ancient Greece, as well as by medieval and modern authorities. Both the miranda and credenda of power are instruments that can be used to assess the claims to the justification of power. In other words, these two instruments of power can be used excessively by hierarchical or authoritarian/totalitarian power structures, such as semi-democracies, fascist states, theocracies, and communist regimes for their justification.

In the history of traditional thoughts, Plato and Aristotle elaborated on the systematic interaction between the miranda of power and the hierarchical regimes in their political works. However, Farabi later developed a unique theory of justification that built-instead of miranda of power-on the credenda of political power, since he found that if power is based on an individual's leadership, then the miranda of power as the only instrument of authority of personalitywhether they are a king or a philosopher-king-is not adequate enough for justification of power. Indeed, Islam as a political religion challenged the traditional miranda of power as well as the modern ones. The Islamic Revolution of 1979 in Iran and emergence of Islamic political parties and movements after the Arab Spring in the Middle East are the example of the transformation of the miranda to the credenda of power.

The miranda of power may be critical for justifying an authority's claim to power, but it lacks the fraternity, obedience, and unity of a political community. With the emergence of divine claims to power, political theorists began to notice that admiration, - that is the miranda of power-was neither general nor natural, and that it was the opinion of a certain class and a product of meticulous training (Jouvenel, 1948: p. 321 [38]). On the contrary, the political discourses of 
the age of Farabi show that if authorities use a combination of admiration and belief from the public, - in other words the credenda of power, then it appears as if the folks justified the power themselves. For the credenda of power requires that folks be self-generators of the belief in power. Because when an idea turns into common religious belief, which is sanctioned by leviathans, gods, and divine beings, no one can question it without the expectation of a militant reaction of believers.

Whether the credenda of power are used for good or bad depends on the power and the nature of the authority. For instance, in the United States of America, voting for a presidential candidate or voting on a civil act, religion, and specifically Christianity, has always played an important role. One of the important arguments used against the slavery, for example, was that "it is a sin" (Danver, 2011: p. 425 [49]). Similarly, we see that the modern theocracies also rely on the credenda of power. However, an excessive reliance of these power structures on the credenda of power may possibly result in oppression and monopolization of power. As a result, an authority denies the essential dignity of human nature, for the sake of a far-off natural theological community that controls the strong impression of divine religious law. Thus, contrary and paradox results are possible by using the credenda of power for justification of power?

Looking at the specific instruments of power invites us to focus on the process of the politicization of folks. The more critical analysis there is of the instruments of power, the better understanding there may be of their causes and effects in the political arena. So, we argue that the Hitler's seizure of power and the long list of similar cases of power transition, namely Mussolini's fascist uprising and Mao's revolutionary achievement, are not merely legal walk overs (Hafez, 2010: p. 117 [50]). We also conclude that political uprisings in the recent years after the Arab Spring of 2011 in the Middle East are not the result of the process of politicization of society. However, the spirit of communities, along with an extreme way to interpret the constitution produce the opportunity for the credenda of power to work with other instruments of power to support stronger authoritarian/totalitarian regimes in which manipulation in all strata of the socio-political lives of individuals are assumed to be justified.

\section{References}

[1] Barker, E. (1959) The Political Thought of Plato and Aristotle. Russell \& Russell, New York.

[2] Aristotle (1995) Politics. Translated by Ernest Barker, Oxford University Press, Oxford.

[3] Svolik, M. (2012) The Politics of Authoritarian Rule. Cambridge University Press, Cambridge. https://doi.org/10.1017/CBO9781139176040

[4] Fu, Z. (1993) Autocratic Tradition and Chinese Politics. Cambridge University Press, Cambridge.

[5] Ariely, D. (2008) Predictably Irrational: The Hidden Forces That Shape Our Decisions. Harper Collins, New York. 
[6] Kuklinski, J. and Quirk, P. (2000) Reconsidering the Rational Public: Cognition, Heuristicsand Mass Opinion. In: Lupia, et al., Eds., Elements of Reason: Cognition, Choice and the Bounds of Rationality, Cambridge University Press, New York, 153-182.

[7] Schacter, D. and Addis, D. (2007) The Cognitive Neuroscience of Constructive Memory: Remembering the Past and Imagining the Future. Philosophical Transactions of the Royal Society of London, 2007, 773-786. https://doi.org/10.1098/rstb.2007.2087

[8] Foucault, M. (1998) The Will to Knowledge, History of Sexuality. Penguin, London.

[9] Taylor, Ch. (1994) Alternative Future: Legitimacy, Identity, and Alienation in Late Twentieth Century Canada. In: Day, M., Ed., Communitarianism: A New Public Ethic, Wadsworth, Belmont, 58-120.

[10] Taylor, C. (1985) Alternative Future: Legitimacy, Identity, and Alienation in Late Twentieth Century Canada. In: Cairns, A. and Williams, C., Eds., Constitutionalism, Citizenship and Society in Canada, University of Toronto Press, Toronto, 183-229. (reprinted in C. Taylor (1993) Alternative Future. In: Laforest, G., Ed., Reconciling the Solitudes, McGill, Queen's University Press, Montreal, 50-120.)

[11] Hayek, F.A. (1944) The Road to Serfdom. University of Chicago, Chicago.

[12] Filmer, R. (1980) Patriarchia: Or the Natural Power of Kings. Printed for R. Chiswel, W. Hensman, M. Gilliflower, and G. Wells, London.

[13] Merriam, E. (1934) Political Power. Collier Books, New York.

[14] Godwin, E. (1806) The Pantheon, or, Ancient History of the Gods of Greece and Rome. Thomas Hodgkins, London.

[15] Sternberger, D. (1986) Grund und Abgrund der Macht: Über Legitimität von Regierungen. [Origin and Abyss of Power: Legitimacy of Governments.] Insel Verlag, Frankfurt am Main.

[16] Fakhry, M. (2002) Al-Farabi: Founder of Islamic Neoplatonism. Oneworld Publication, Oxford.

[17] Mahdi, M.S. (2001) Alfarabi and the Foundation of Islamic Political Philosophy. University of Chicago Press, Chicago.

[18] Shokri, M. (2013) Strauss's Farabi. Studia Humana, 2, 2.

[19] Simmons, J. (2001) Justification and Legitimacy. Cambridge University Press, Cambridge.

[20] Barnard, F. (2001) Democratic Legitimacy: Plural Values and Political Power. McGill-Queen's University Press, Montreal.

[21] Arendt, A. (1986) Communicative Power. In: Lukes, S., Ed., Power, New York University Press, New York.

[22] Nye, J. (2004) Soft Power: The Means to Success in World Politics. Publication Affair, New York.

[23] Kelsen, H. (1928) Sociological and Legal Concept of State: A Critical Inquiry into the Relationship between State and Law. ScientiaVerlag, Aalen.

[24] Lynch, J. and Adamo, P. (2014) The Medieval Church: A Brief History. Routledge, London.

[25] Plato (n.d.) Republic.

[26] Shokri, M. (2016) Islam and Politics: The Case of the Islamic State. Studia Humana, 5, 2. https://doi.org/10.1515/sh-2016-0006

[27] Farabi (2011) The Attainment of Happiness. In: Parens, J. and Macfarland, J.C., Eds., Medieval Political Philosophy: A Sourcebook, Cornell University Press, New York. 
[28] Farabi (1985) On the Perfect State. In: Walzer, R., Ed., Al-Farabi on the Perfect State, Oxford University Press, Oxford.

[29] Nasr, S. and Leaman, O. (1996) History of Islamic Philosophy. Routledge, London.

[30] Campagna, N. (2010) Alfarabi: Denken Zwischen Orient und Okzident. [Farabi: Think between Orient and Occident.] Parodos Verlag, Berlin.

[31] Hammond, R. (1947) The Philosophy of Alfarabi, and Its Influence on Medieval Thought. The Hobson Book Press, New York.

[32] Plato (n.d.) Apologia.

[33] Farabi (2004) Enumeration of Science. In: Selected Aphorisms, Cornell University Press, New York.

[34] Steinschneider, A. (1966) Des Arabischen Philosophen Leben und Schriften. [The life and Wrtings of Arabic Philosophers: Farabi.] Philo Press, Amsterdam.

[35] Farabi (n.d.) Ketāb al-sīāsah. [Book of Politics.]

[36] Spearman, D. (1934) The Psychological Background of Dictatorship. The Sociological Review, 26, Online. https://doi.org/10.1111/j.1467-954X.1934.tb01905.x

[37] Hone, W. (1821) The Right Divine of Kings to Govern Wrong: Dedicated to the Holy Alliance. Printed for William Hone, London.

[38] Jouvenel, B. (1948) On Power, Its Nature and the History of Its Growth. Viking, New York.

[39] Farabi, (1961) Aphorisms of the Statesman. Al-Madani, F., Trans., Dunlop, D.M., Introd. Cambridge University Press, Cambridge.

[40] Weber, M. and Winckelmann, J. (1969) Die Protestantische Ethik und der Geist des Kapitalismus. [The Protestant Ethics and the Soul of Capitalism.] Siebenstern-Taschenbuch-Verl., Hamburg; München.

[41] Mayer, F. (1950) A History of Ancient \&Amp; Medieval Philosophy. American Book Co, New York.

[42] Farabi, (2011) Selected Aphorism. In: The Political Writing, Butterworth, C., Trans., Cornell University Press, New York.

[43] Desmond, W. (2011) Philosopher-Kings of Antiquity. Continuum Intl Pub Group, London.

[44] Gentile, E. (2006) Politics as Religion. Staunton, G., Trans. Princeton University Press, Princeton.

[45] Saikal, A. and Schnabel, A. (2003) Democratization in the Middle East: Experiences, Struggles, Challenges. United Nations University Press, Paris.

[46] Lewis, G. (1999) The Turkish Language Reform: A Catastrophic Success. Oxford University Press, Oxford.

[47] Harper, S.N. (1929) Foreign Governments and Politics: The Communist Party of the Soviet Union. The American Political Science Review, 23, 956-971. https://doi.org/10.2307/1946498

[48] Arendt, A. (1948) The Origins of Totalitarianism. Schocken Books, New York.

[49] Danver, L. (2010) Revolts, Protests, Demonstrations, and Rebellions in American History: An Encyclopedia. ABC-CLIO, Santa Barbara, CA.

[50] Hafez, K. (2010) Radicalism and Political Reform in the Islamic and Western Worlds. Skinner, A., Trans. Cambridge University Press, Cambridge. https://doi.org/10.1017/CBO9780511778957 
Submit or recommend next manuscript to SCIRP and we will provide best service for you:

Accepting pre-submission inquiries through Email, Facebook, LinkedIn, Twitter, etc. A wide selection of journals (inclusive of 9 subjects, more than 200 journals)

Providing 24-hour high-quality service

User-friendly online submission system

Fair and swift peer-review system

Efficient typesetting and proofreading procedure

Display of the result of downloads and visits, as well as the number of cited articles Maximum dissemination of your research work

Submit your manuscript at: http://papersubmission.scirp.org/

Or contact jss@scirp.org 